\title{
Analyzing the Effectiveness of Training Programs of BCS Administration Academy: Prospects and Challenges
}

\author{
Shah Md. Azimul Ehsan \\ Lecturer \\ Department of Public Administration \\ Jagannath University, Dhaka, Bangladesh \\ Email: ehsan.azim@yahoo.com
}

Zaki Imam

Former Director (Administration and Finance)

National Academy for Educational Management (NAEM)

Ministry of Education (MoE), Dhaka, Bangladesh

Email: zimam37@yahoo.com

Received: Sept. 26, 2020 Accepted: Oct. 26, 2020 Online published: Nov. 10, 2020

doi:10.5296/jpag.v10i4.17740～URL: https://doi.org/10.5296/jpag.v10i4.17740

\begin{abstract}
The specific objective of this study was to analyse the effectiveness and the challenges of the training programs imparted by BCSAA, a leading training institution for the BCS administration cadre officials in Bangladesh. The study is qualitative in nature that used data from both primary and secondary sources. Primary data was obtained by interviewing a total of 75 participants from 113th, 114th and 115th Law and Administration Course (LAC) using semi-structured questionnaire and phone in interview. While secondary data was collected adopting content analysis technique through reviewing books, journal articles, e-resources, unpublished monographs and newspapers. Analysing the data from both the sources, the study has found that the training program of LAC has been effective to a certain extent as it has helped its participants to achieve some core qualities relevant to their job performance. The findings of the study also suggest that due to the intervention of this training, trainees
\end{abstract}


have improved their knowhow about land management, conducting mobile courts, magisterial duties, e-filing, e-mutation etc. Furthermore, the training has resulted in significant improvement of their communication skills particularly in English, presentation skills, public speaking and in few other areas of their professional needs. However, the respondents raised few concerns about certain aspects of the training which include absence of proper need assessment for training, heavy reliance on guest speakers, huge syllabus compared to the course duration, absence of e-library facilities in the academy, sessions being mostly lecture based, absence of refreshers training etc. Nonetheless, this study has come up with certain pragmatic recommendations drawing on the narratives from the respondents. BCSAA need to address these issues with utmost priority for making this training further effective.

Keywords: training, administration, skills, effectiveness, challenges, Bangladesh

\section{Introduction}

Training is used to indicate a systematic, conscious and planned mechanism for acquisition of ASKs; i.e. attitudes, skills and knowledge by employees which results to improved performance in a particular environment (Kabir \& Baniamin, 2012; p.03). Emphasizing on the need of training, Pundit Jawaharlal Nehru said, 'Training is expensive. However, without training, it is more expensive'. In Robbins words, 'competent employees don't remain competent forever. Skills deteriorate and can become obsolete. Sapru (1985) echoing on the importance of training expounded that 'no matter how well qualified an individual may be at the time of entry, one lacks certain qualities which one needs to acquire for efficient discharge of ones duties in a specific post'. That's why organizations spend billions of dollar each year on formal training' (Sapru, 1985).

Training is expected to boost a civil servant's efficiency and effectiveness to the highest possible level. The basic objective of training in public administration is to provide professional knowledge, broader vision, appropriate management skills and correct behaviour patterns. (Sapru, 1985). Training creates the opportunities not only for improved individual performance but it also has a great potential for organizational development. This is the reason why civil service training has to maintain its vitality, and improve its efficiency and quality to provide its own increased input in terms of better trained and more efficient administrative manpower (Jahan \& Monem, 2014).

Consequently, global issues have emphasized the importance of training effectiveness as the essence of developing and managing quality human resources. Every year, a large amount of money is allocated for training investment. For example, Powell (2009) noted that U.S.A. spent as much as $\$ 134.39$ billion annually on such programs. Griffin (2010) indicated that The National Employer Skills Survey in 2007 estimated that employers in the U.K. spent a total of $£ 38.6$ billion annually in training. In developing country, such as Malaysia, training is also a major concern, in which employers must annually contribute at least one per cent from their employees' salary for training fund (Chong, 2005; Abdullah \& Yazam, 2009).

Following the trend of both the developed and the developing countries, Government of 
Bangladesh (GOB) also have stressed upon training issues of public bureaucracy in order to make it more modernized, further competent and accustomed with the modern management tools. A holistic approach for training civil servants has been adopted in Bangladesh civil service through the enunciation of a Public Administration Training Policy (PATP) in 2003, which is a qualitative improvement on past policies (Ali, 2007). It is stated in the policy that public sector training institutions would devise need-based, result oriented and market-responsive training programs aimed at building professionalism of public servants at different levels. In order to translate the policy commitments into reality, huge investment is required in this sector. Evidences suggest that GOB have been spending significant portion of the annual budget for achieving this objective. For instance, in the fiscal year 2017-2018, amount of revenue budget allocated for Bangladesh Public Administration Training Centre (BPATC), Bangladesh Institute for Governance and Management (BIGM), Bangladesh Institute for Administration and Management (BIAM) and Bangladesh Civil Service Administration Academy (BCSAA) was 68.28 crore Tk., 8 crore Tk., 2.29 crore Tk. and 18.1 crore Tk. respectively (MOPA, 2018). Moreover, for enhancing the capacity of BCSAA, which is a leading training institution providing basic course on Law and Administration to BCS (Administration) cadre officials, GOB allocated 10.99 crore Tk. during the same period. Meanwhile, 22.48 crore Tk. was allocated for the expansion of academic building and further improving the existing facilities of training in the academy (MOPA, 2018). All these reflect the strong commitment of the government in making the BCS (administration) cadre officials more efficient and effective. There is no denying the fact that the investment in this sector is a time befitting one and is expected to have high returns in the long run which might further prompt government to increase the allocation. Nonetheless, it is imperative to measure the effectiveness of these training programs in order to find out what is working, how much is working and where added attention would be needed by the state actors.

As a matter of fact, this study aims to measure the effectiveness of the training programs of BCSAA only. The rationale for doing so is that a good number of studies have been conducted for measuring the effectiveness of various training programs of BPATC, the apex training institute for the civil servants of Bangladesh, of which Huq \& Saifullah (1989); Ali, Islam \& Quadir (1998); Roy (2007); Hasan (2009) and Kabir \& Baniamin (2012) are noteworthy. On the contrary, there is dearth of empirical studies which have been conducted with special focus to BCSAA. Hayatullah (2006) in his study found that most of the participants of 'Law and Administration Course' could apply the acquired knowledge and skill in the respective field of work in appropriate or prescribed manner and thus concluded that the training moderately helped Bangladesh Administrative Service officers to achieve some core qualities relevant to their job performance. However, he noted few challenges which the program was facing like absence of training need assessment while setting training objectives, issues related to the heavy dependency on guest speakers and absence of refreshers training. While Rezvi (2013) noted that 'Law and Administration' course (LAC) though apparently found comparatively effective in terms of creating law base of the officers but it failed to achieve its explicit objectives in terms of getting continuous feedback of the officers and incorporate the same in the training method. Moreover, lack of research and lack of arranging refresher courses made this course further out dated. 
Albeit some challenges have been identified in the exiting literature, these studies are relatively old which begs a question about the validity and reliability of those data in present context. Again, the latest training manuals and annual reports of BCSAA clearly states that there is mechanism of taking feedback from trainees which are later incorporated in the program designing. Moreover, off late, government expenditure has increased remarkably for enhancing the existing capacity of BCSAA. It means that there is already a wave of change in BCSAA training mechanism. Nevertheless, for drawing inference and making objective analysis about the performance evaluation of BCSAA, this empirical study would be worthwhile and timely one. On one hand, the findings of this study will help to fill the void in the literature and on the other hand, it will assist concerned policy makers to get the real picture of both the prospects and the challenges of the training program of BCSAA, i.e. (Law and Administration Course).

\section{Research Objectives}

The research question of this study is:

○ To what extent BCSAA is being able to impart training effectively to its participants?

$\circ$ If not, what challenges is it facing currently and what are the ways of overcoming those?

Aligning with the research questions, the specific objectives of this study are:

$>$ To analyze the role of BCSAA in imparting training, especially the Law and Administration course (LAC)

To suggest strategies for maximizing the effectiveness of the training programs in BCSAA

\section{Methodology of Study}

This study is highly descriptive in nature. It has adopted qualitative methods of social research for collecting and analyzing data. Firstly, the study employed content analysis method where several books, articles, reports published both in national and international journals and other relevant literatures on this topic were reviewed. This has provided in-depth understanding of the training approach of BCSAA. Secondly, a perception study was undertaken on the participants of 'Law and Administration' Course (LAC) for assessing the overall effectiveness of BCSAA. A survey questionnaire was used for knowing the necessary information from the respondents. The survey questionnaire had both open ended and close ended questions for getting both qualitative and quantitative data. The total sample size was 75 , who were selected adopting the purposive random sampling technique from the $113^{\text {th }}$, $114^{\text {th }}$ and $115^{\text {th }}$ LAC. Among the total respondents, number of male and female was 54 and 21 respectively. It needs to be mentioned here that the number of female respondents were less because in each LAC, the ratio of male and female participants is 3:1. Owing to current Covid-19 situation, the researchers could not use the face to face interview technique. However, wherever there was confusion or the researchers felt that more clarification is needed for a particular reply given by a respondent, phone in interview technique was adopted. 


\section{Conceptual and Theoretical Perspectives}

\subsection{Key Factors for Effective Training}

There are some key factors that make a training program effective. One of the most important and first most step during designing a training program is conducting a training needs analysis (Goldstein \& Ford, 2002). A training need analysis allows training designers to understand several critical aspects of the training program: (a) where training is needed (b) what needs to be trained and (c) who needs to be trained (Goldstein, 1993). Moreover, training need analysis also provide with some valuable information about fixing the learning objectives, shaping the design and the delivery of the training and development of criterion. Gautam \& Gautam (2011) noted that if training needs are not properly analyzed, then training programs may have wrong contents, objectives and the methodology of training might be a faulty one. All these will result to low returns and unexpected outcomes from such trainings.

Once need analysis is done and gaps become well identified, the next stage is to set the training objectives. While setting the training objectives, it is very important to keep the objectives as specific and précised as possible for the sake of better comprehension of both the trainers and the trainees. Noe (1986) argued that training objectives can turn out a valuable tool for evaluating the performance of the trainees which will also help to measure the effectiveness of the training programs. After setting the objectives, designing the training program becomes inevitable where many important decisions are taken about which course content and modules should be included, who would be the appropriate participants to include in the training, who would be the resource persons, what range of delivery techniques would be used, how the sessions would be planned, etc. Stressing on the importance of selecting proper training techniques and transfer of knowledge to the targeted people, Kabir \& Baniamin (2012) expounded that only ensuring a comprehensive training curriculum will not be adequate to achieve the ultimate objective of a training program; rather, the proper selection of training techniques and transfer of knowledge to the targeted people are also very crucial. That's why both these factors have become increasingly important aspects of training. However, the actual transfer of training depends a lot on the quality of trainer/resource person because they can remove the mental block of trainees and motivate them to learn by deleting the negative perception of the trainees regarding the training (Towler \& Dipboye, 2001).

Quite astonishingly, another crucial factor that is most often ignored by the training management, which have a significant influence on the effectiveness of the training program is the 'institutional environment'. It includes the classroom arrangement - seating pattern, light arrangements, AC/ fan placements, audio system, materials provided, food, tea, snacks, dormitory, library, dining and internet facilities (Gagne \& Medsker, 1996). Finally, training evaluation provides feedback on whether a training program works or not, which parts of it are effective or ineffective and which parts need to improve or negate. For objective evaluation of training programs, effective evaluation models are necessary to inform trainers and researchers of the added value of their program (Kabir \& Baniamin, 2012, p.06). 


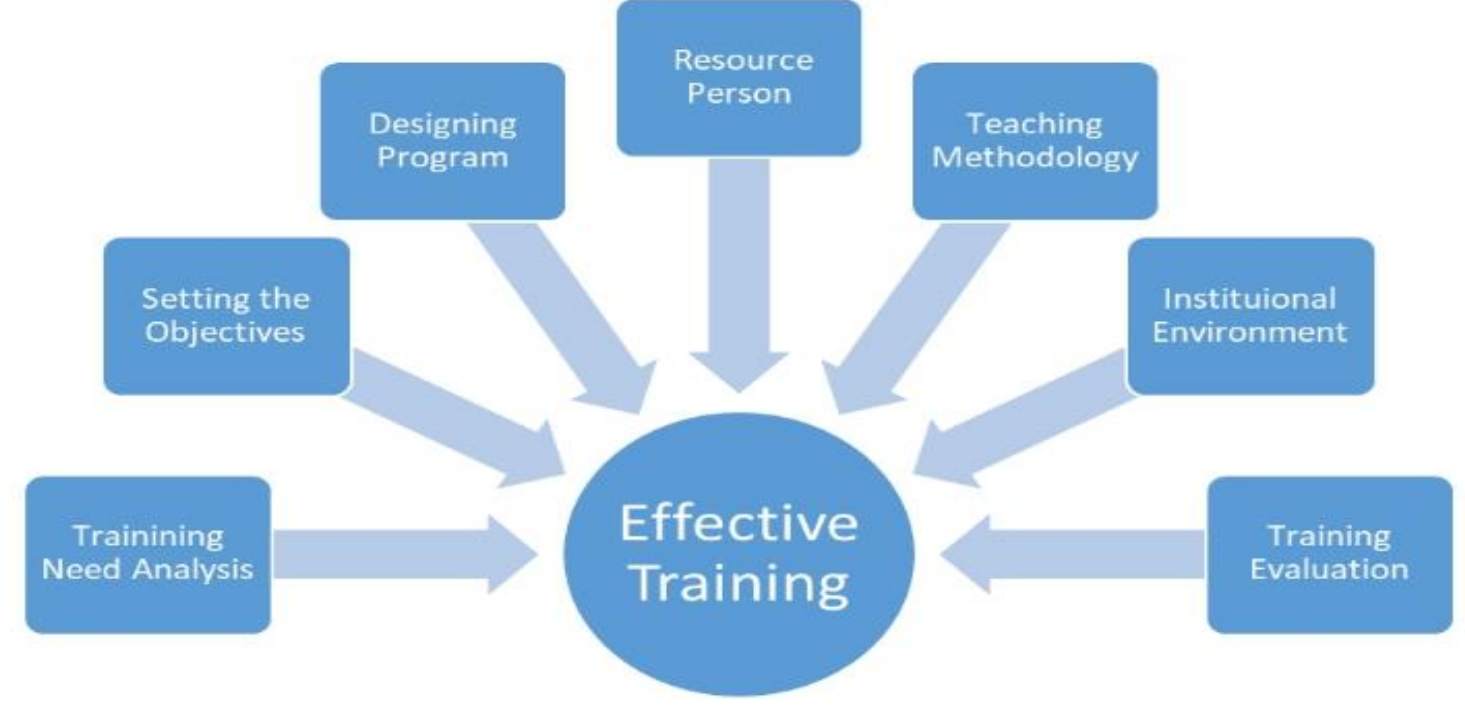

Figure 1. Key Factors for effective training ${ }^{1}$

\subsection{Measuring Training Effectiveness}

Training effectiveness is a crucial aspect to determine the returns on human resource development (HRD) investment (Noe, 2010; McGuire \& Jorgensen, 2011; Werner and DeSimone, 2012). Overall training effectiveness (OTE) is the extent to which the training objectives are achieved and benefited for the company and trainees. It can be evaluated using the combination of satisfaction, learning performance, individual performance, and organizational performance (Goldstein, 1986; Kirkpatrick, 1996; Holton, 2005; Tai, 2006; Bersin, 2008; Noe, 2010). There are various theories or models which have been developed by scholars for evaluating training effectiveness. These include-

- Kirkpatrick's four stage model (Reaction, Learning, Behavior \& Result)

- A.C. Hamblin's Model Reaction (Learning, Job behavior, Functioning)

- Peter Warr's CIPO Mode (Context, Input, Process, Outcome (Immediate outcome, Intermediate outcome, Ultimate outcome)

- B.R. Virmani \& Premila Seth (Pre-training context, Training input, Post-training reaction, Learning, Job improvement plan, On the job, Follow up and transfer)

- Peter Bramley's Model of Evaluation (During the event, After the event, Learning, Behavior, Effectiveness)

- David Reay's Three Phase Model (Trial, On-going and Final)

However, among all these, Kirkpatrick's (1959) model continues to be the most preferred framework to evaluate training effectiveness, either by researchers or practitioners of its simple and practical approach (Holton, 1996; Leach \& Liu, 2003; Kirkpatrick \& Kirkpatrick, 2010;; Giangreco, et al. 2010; Griffin, 2010) (Cited in Aziz, 2013; Dash, Das \& Dash 2019).

Kirkpatrick (1976) four stage model (See figure 02) include (1) trainee reactions (i.e., what trainees think of the training), (2) learning (i.e., what trainees learned) (3) behaviour (i.e., how trainees behaviour changes), and (4) organizational results (i.e. impact on the

\footnotetext{
${ }^{1}$ Developed by authors
} 
organization). Reactions as assessed by asking trainees how well they liked the program. Learning is measured by examining the extent to which trainees have acquired the principles, facts or skills trained. Changes in behaviour are assessed by evaluating trainees' performance back on the job. Finally, organizational results that are assessed include turnover, reduced cost, improved efficiency and improved quality (Cited in Kabir \& Baniamin, 2012, p.12).

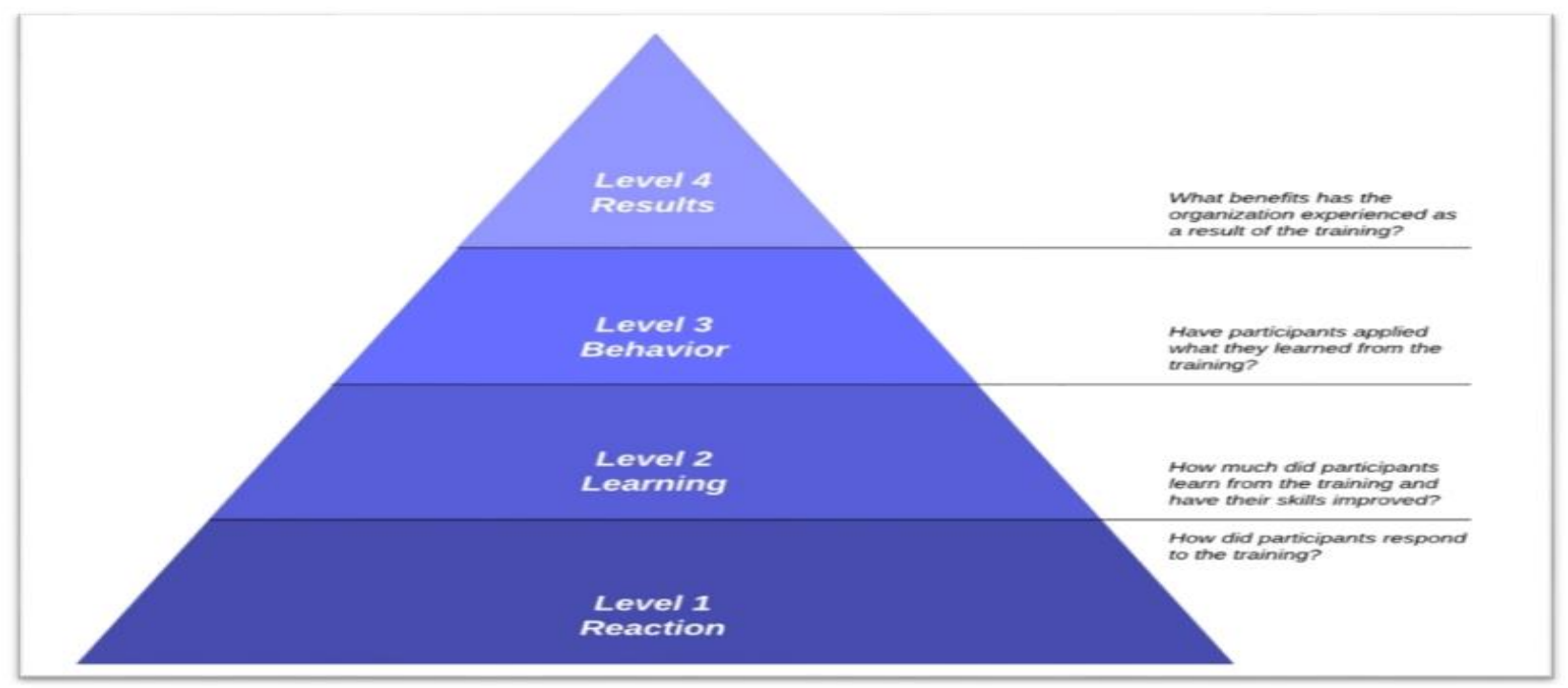

Figure 02. Kirkpatrick Evaluation Model of training evaluation ${ }^{2}$

Most of researchers including Cervero (1988) and Quinones (1997) agreed that each level in the Kirkpatrick's (1959) model measures a different dimension, each have its own purpose and hence can be effectively used to determine the training effectiveness. Bersin (2008) argued that positive reaction towards training can be a powerful tool to predict training effectiveness. This is supported by a study conducted by Ghosh and his colleagues (2011), where they used 'reaction' as a parameter for measuring the effectiveness of training and found how precisely it could explain the improvements obtained by the trainees from that particular training program.

Additionally, many HRD researchers and practitioners used only one selected level for evaluating effectiveness of training. To exemplify, Hand, Richards, \& Slocum-Jr. (2017) focused only on job performance (individual performance); Baldwin, Magjuka, \& Loher (1991) focused only on learning performance and Ghosh et al. (2011) focused only on reaction to training (satisfaction). In the recent times, the popular Six Sigma approach focuses only on customer satisfaction or a part of organizational performance (Bersin, 2008). Interestingly though, few other HRM researchers have used more than one indicator and collecting data from multiple sources, in order to measure the degree of overall effectiveness of the training programs. For instance, Horgan \& Muhlau (2006) used the combination of skills acquired (learning performance) and job performance (individual performance) as the measurement of training effectiveness in HR system for determining the

\footnotetext{
${ }^{2}$ Source: Available at (https://www.lucidchart.com/blog/how-to-use-the-kirkpatrick-evaluation-model)
} 
impact of HR system on employee performance among two different countries (Ireland and Netherland).

Interestingly, Giangreco, Sebastiano and Peccei (2009) indicated that only large firms tend to use level three and four while they adopt Kirkpatrick model, however, most of small firms never gone beyond level one and two because of the complexity in evaluation process. This argument is consistent with findings of Chong (2005) who showed that from 106 manufacturing companies in Malaysia, 35\% evaluated the reaction, 25\% evaluated learning changes, $16.5 \%$ evaluated the behavioural changes, $11 \%$ evaluated results, and $12.5 \%$ did not organize any training evaluation. According to Kirkpatrick, the higher the level of training effectiveness, the more difficulties, complexities, and expensive to measure it; this explains why it is very difficult to evaluate the complete levels of training effectiveness.

Following the trend of these researchers, in order to meet the research objective, this study have adopted combination of two parameters (instead of taking all the four parameters as suggested by Kirkpatrick). That is, the study have used first two levels of Kirkpatrick's model which include reaction and learning (See figure 02). Generally, evaluations at level one (reaction phase) will include "how did the participants respond to the training?'. That is, the study will figure out their reaction and rate of satisfaction about content of training, training sessions, training materials, quality of the trainers, over all institutional facilities of BCSAA, perception about the evaluation system and some other relevant facts. At level two, the study will be assessing their learning level. More specifically, questions would be asked what difference have this training made to their ASK, what value has this training added to their knowledge base and how are they applying their acquired knowledge from training at their previous/current work places.

\section{Synopsis of BCSAA and LAC}

BCSAA, situated at Shahbagh, Dhaka, is the focal-point of national training Academy for the members of BCS (Administration) cadre. It is an attached department under the administrative control of the Ministry of Public Administration (BCSAA, 2016). Figure 03 illustrates the vision, mission and goals of BCSAA. 


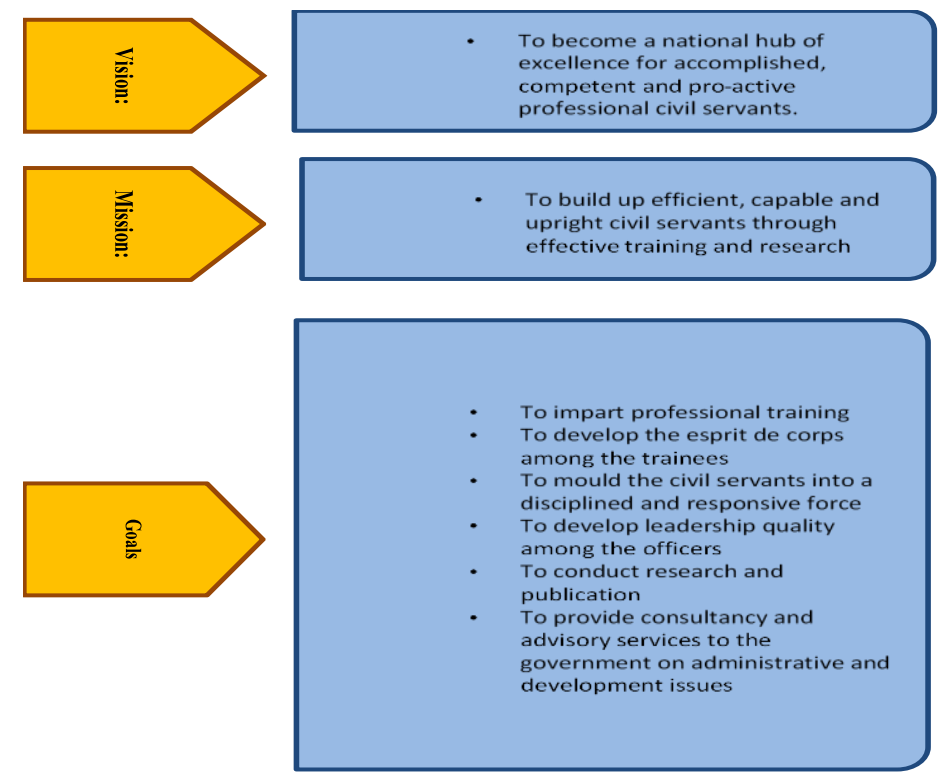

Figure 03. BCSAA’s Vision, Mission and Goals ${ }^{3}$

At present, the Academy offers various types of courses ranging from short term to long term for the junior and the mid-level officers of BCS Administration and other cadres. BCSAA is well equipped with various types of institutional facilities for imparting effective training programs which include two multi-storied buildings equipped with modern facilities, two computer labs and one cyber center, multimedia classrooms and a rich library which houses about 45 thousand plus books on various subjects and good number of reputed journals. The academy also have the options for the participants to get engaged in outdoor games like Badminton, Basketball, Lawn Tennis and Volleyball where, at a time, 120 participants can play in these courts (BCSAA, 2016; BCSAA, 2019).

There are also options for trainees who prefer for indoor games and exercise facilities instead of the outdoor ones. Moreover, there is a well-furnished recreation room with TV, music system, etc. In case any participant gets sick during his/her stay at the academy, there is full-time medical officer and pharmacist who ensure the primary health care in case of emergency (BCSAA, 2018; Ehsan, 2014).

When it comes about the faculty members, BCSAA has a rich, competent committed and well-performing 19 faculty members in total of which, about one-third of them have foreign $2^{\text {nd }}$ Master's degree. In addition to that, BCSAA has a pool of knowledgeable resource persons (which is updated regularly) including professors, current and retired civil servants, barristers, political leaders, and eminent civil society personalities who are frequently invited as guest speakers to conduct classes on various topics depending on the nature and needs of the courses. The strength of BCSAA lies in analyzing the training methods of similar training academies worldwide and incorporating those in the training module accordingly. The Academy is successfully maintaining regional/Asian standard in this regard (BCSAA, 2019).

\footnotetext{
${ }^{3}$ Adopted from (BCSAA 2016, p.13)
} 


\section{Macrothink}

Perhaps, the most important training program that is imparted by BCSAA is Law and Administration Course (LAC), an elementary training for the newly recruited administrative service officers (Assistant Commissioners and Assistant Secretaries) focusing on the areas of law and administration. It is also a prerequisite for them to complete this course successfully in order to confirm their service (Rezvi, 2013). Ministry of Public Administration (MOPA) nominate the participants for taking part in this course. It is a residential training with a duration of five months.

Completion of the course successfully will facilitate the participants with the ability to -

$>$ understand the norms and values of civil service

$>$ perform the magisterial and administrative functions efficiently

$>$ acquire knowledge and good understanding on land management system

$>\quad$ ensure good governance and administration for development

$>$ facilitate in the process of team building

$>$ earn a good command in communication, research and presentation skills

$>$ acquire knowledge on ICT

Contents of LAC are designed and updated through a regular process of review by the academy based on the feedbacks from trainees, opinions from professionals and guest speakers. There are in total 21 modules in LAC. The faculty members and the guest speakers conduct the sessions using a range of methodologies like- (i) lecture, (ii) lecture followed by discussion , (iii) group discussion, (iv) role-play, (v) brainstorming, (vi) syndicate discussion, (vii) field visit, (viii) book review, (ix) simulation exercise etc.(BCSAA, 2019).

\section{Data Findings and Analysis}

\subsection{Perception about Law and Administration Course: Viewing Through Trainees Lenses}

One of the most important factor which determine the effectiveness of training programs is 'well defined training objectives'. The data obtained from the respondents reveal that almost $50 \%$ felt that the objectives of the course was clearly defined; whereas $15 \%$ of the respondents endorsed this fact with more emphasis. However, $15 \%$ of the respondents felt otherwise about the training objectives and $20 \%$ opted to have a neutral position regarding this particular question (See figure 04). 


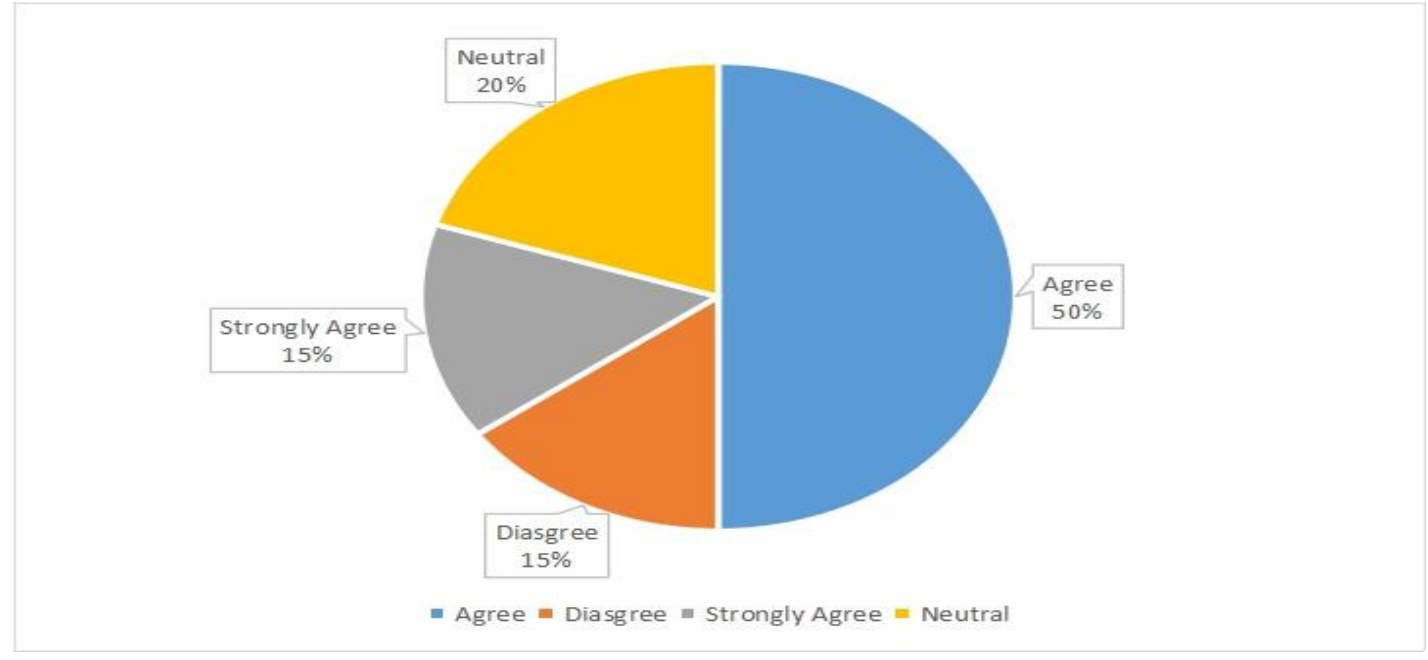

Figure 04. Were training objectives clearly identified?

Trainings being well defined might not bring expected results if the participants whom are to be trained don't know thoroughly what the purpose of the training is, what the expectations from the course are and what difference will the training make to their existing knowledge. This sort of uncertainty of the trainees can be removed if the training objectives are thoroughly discussed with them prior to the training sessions. Around $58 \%$ of the respondents agreed to the fact that the trainers discussed in details about the course expectation. Nevertheless, few respondents (23\%) disagreed about this and opined that they had very little idea about the training objectives because it was not rigorously talked about at the advent of the training sessions (see table 01).

Table 1. Training Objectives were thoroughly discussed prior to the training sessions

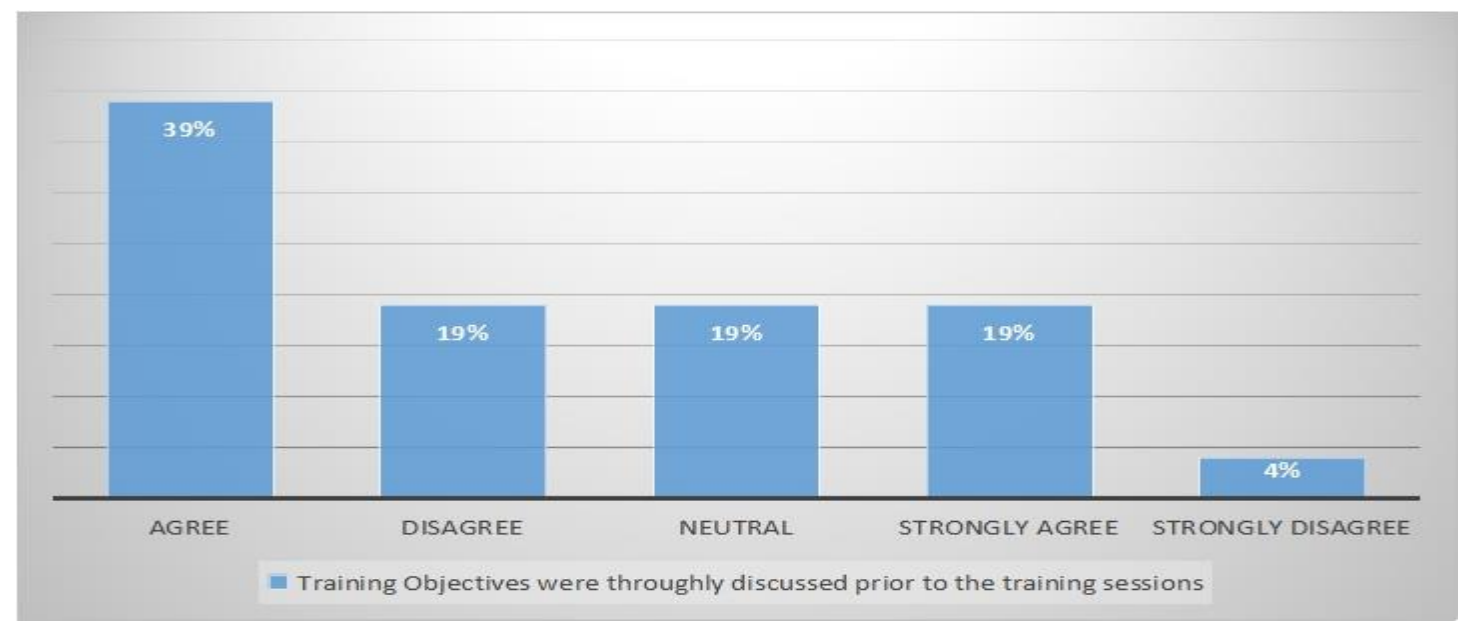

Regarding the question whether the training objectives of the course was entirely achieved, respondents replied quite distinctively. $43 \%$ of the total respondents agreed that the objectives were achieved in totality. Interestingly though, $39 \%$ of the respondents disagreed about this (See figure 05). 


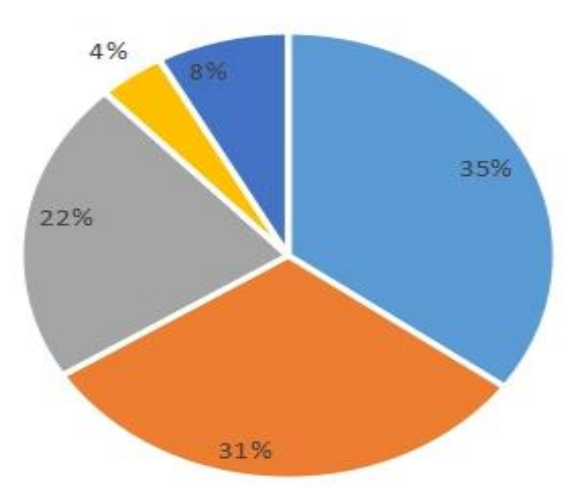

- Agree $=$ Disagree $=$ Neutral $=$ Strongly Agree $=$ Strongly disagree

Figure 05 . Has the training objectives been achieved in totality?

Another factor which gives information about the effectiveness of any training program is the 'training content'. When the respondents were asked about the content of this course, i.e. about all the 21 modules of LAC, a significant portion of them, around $88 \%$ agreed that the training content is related to the professional needs and only $12 \%$ of the respondents had negative perception about training content (See figure 06).

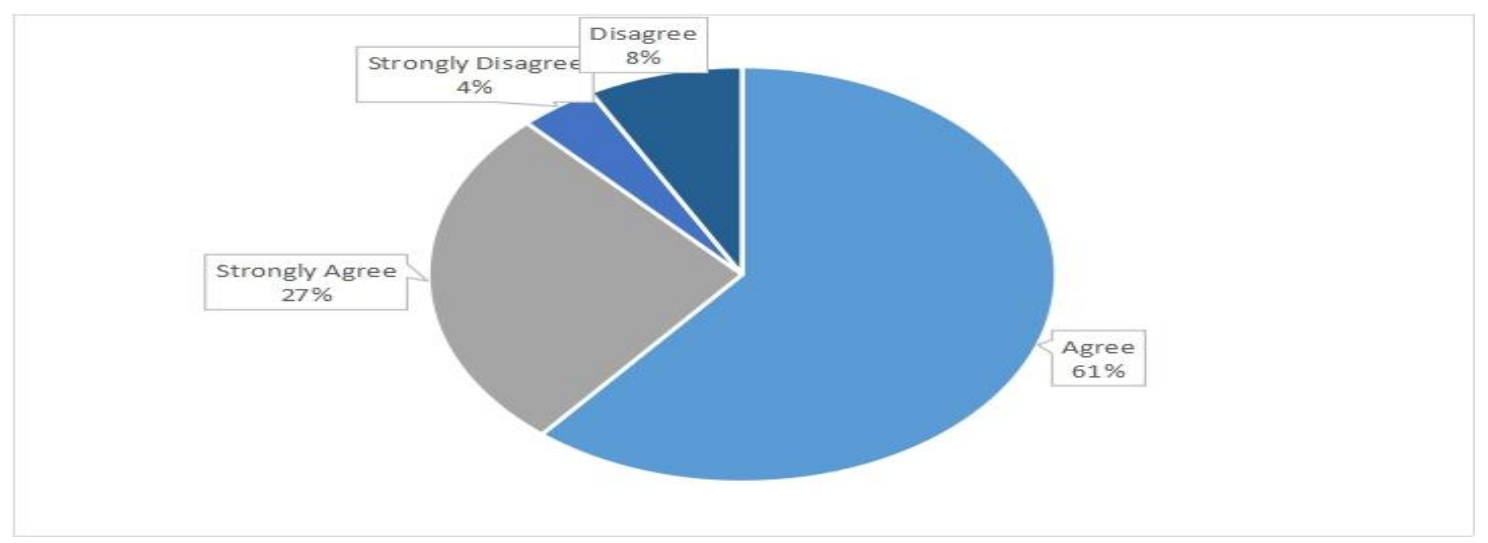

Figure 06. Content of the training is related to the professional needs

About the presentation of sessions, $42 \%$ and $27 \%$ of the respondents opined that it was well and moderately organized. While $31 \%$ respondents' perception regarding this matter was that it was not well organized (see table 02). 


\section{Macrothink}

Table 02. Presentation of the sessions

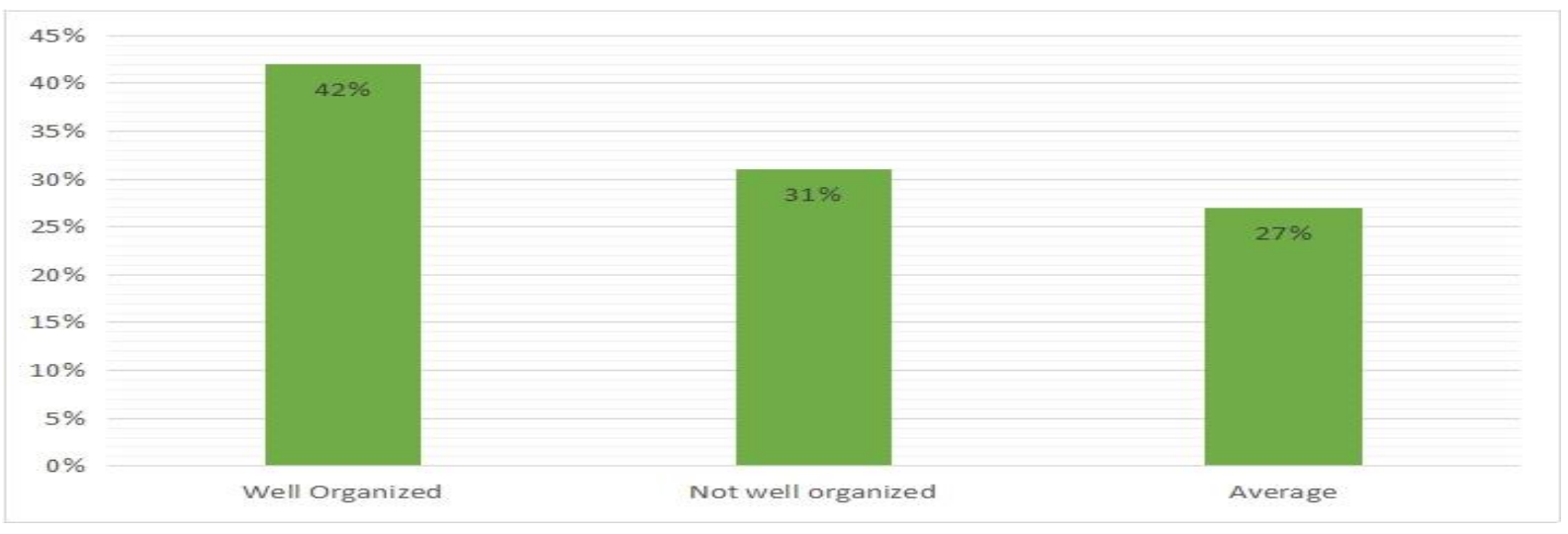

A training might not bring expected results and lose its effectiveness despite having clear objectives and rich content which address the professional needs in case the duration of session remains very short. It then becomes very much challenging for the trainers to give their best input. $61 \%$ of the total respondents felt that the session duration was sufficient enough for delivering the content effectively. On the other hand, 20\% had divergent notions about that and they argued that the session durations were inadequate for ensuring quality delivery of the course contents (See figure 07).

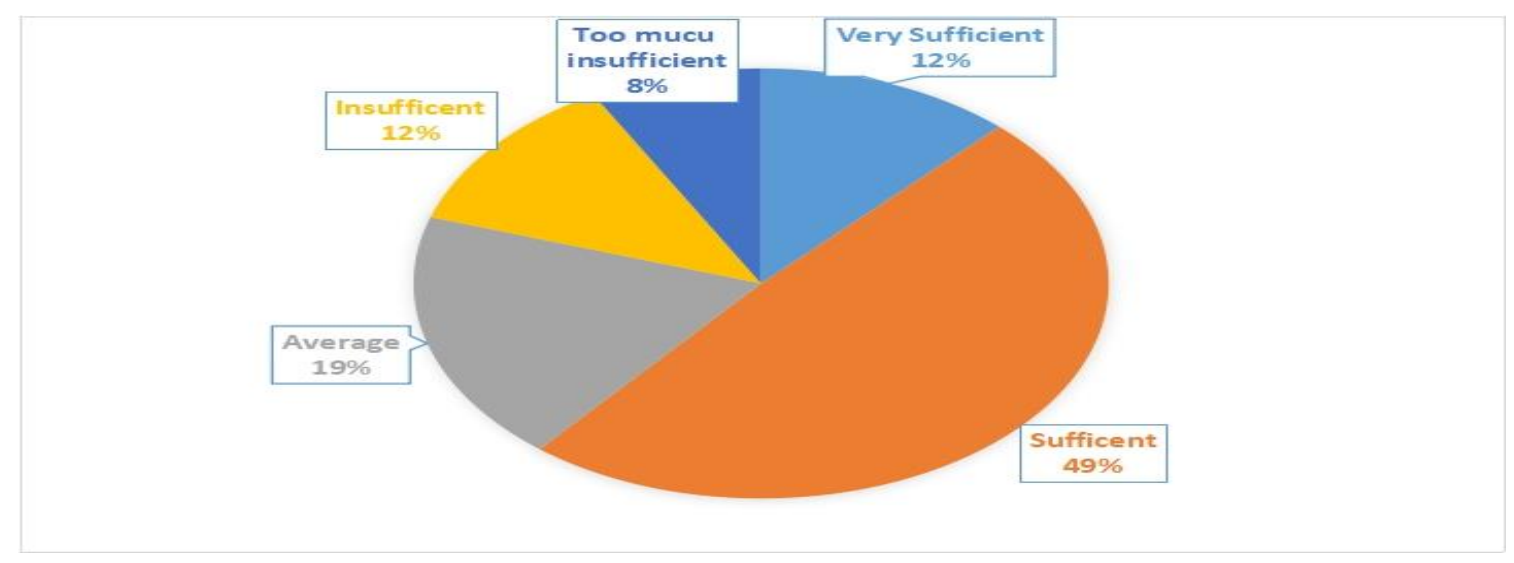

Figure 07. Session duration for effective delivery of content

Perhaps, one of the most dominant parameter which signals the effectiveness of training programs is the quality of the trainers. To be more precised, the trainers should be well conversant about the objectives and the content of the training program. The feedback from the respondents regarding the trainers is that $50 \%$ felt that they were well versed about the objectives and training's content. However, $31 \%$ were unsure about this and $19 \%$ did not agree with the opinion of other fellow course mates. Rather, they disagreed that the trainers lacked proficiency regarding those matters (See figure 08). 


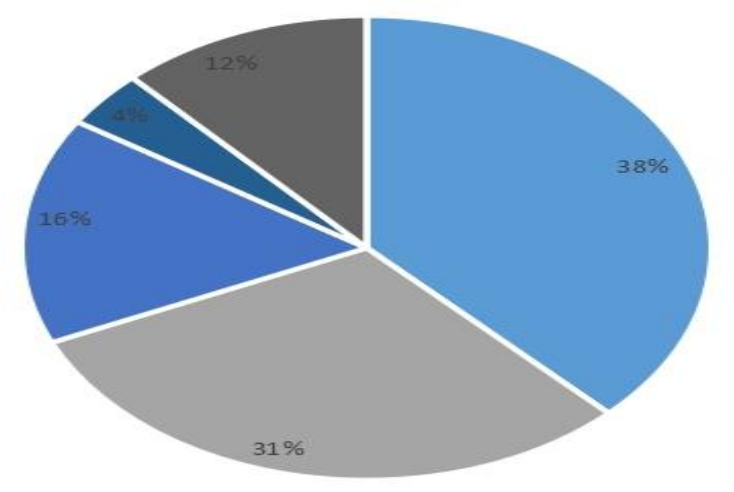

Figure 08. Trainers' proficiency regarding the training objectives and training content

BCSAA has both in-house trainers and a resource pool of qualified guest speakers. However, it is important to strike a proper balance while allocating the sessions among them. $62 \%$ of the respondents opined that the training was heavily dependent on guest speakers. Interesting to note here that only $16 \%$ felt that the sessions were mostly taken by in house trainers (see figure 09).

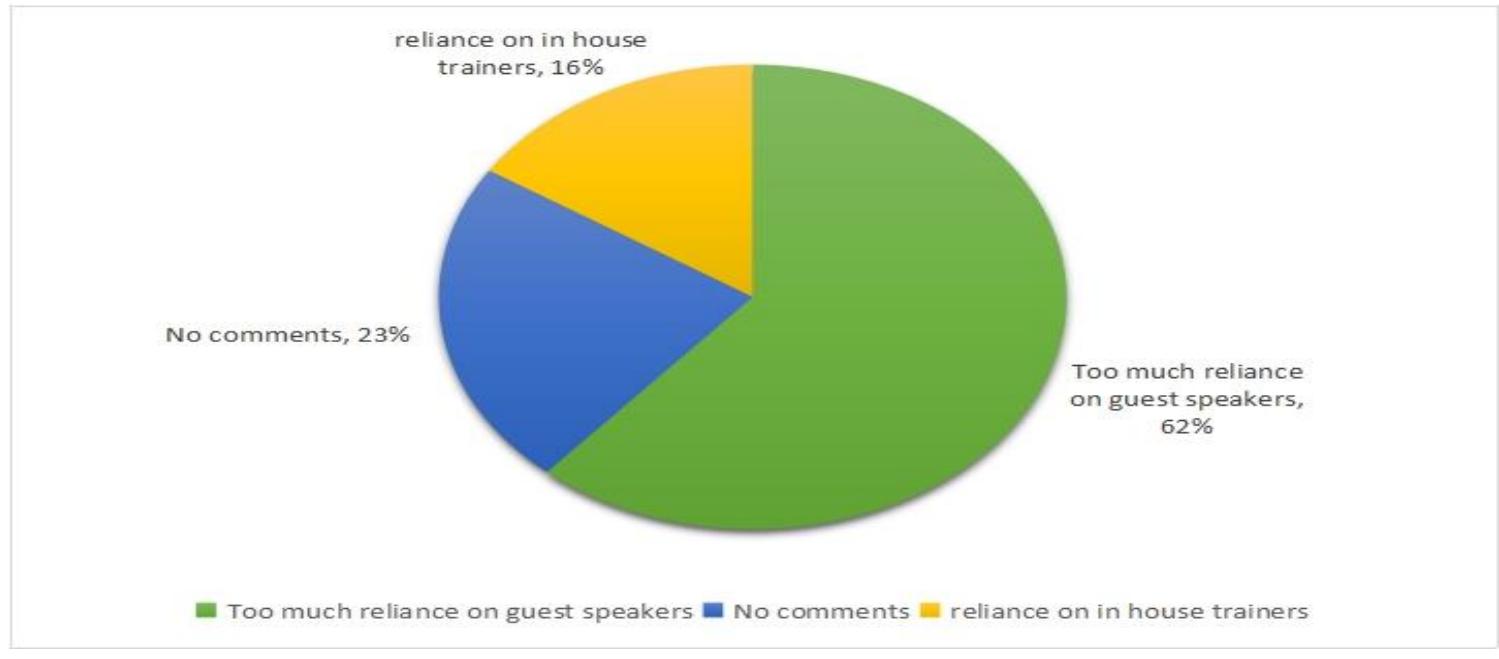

Figure 09. Dependence on guest speakers

According to the guidelines of 'Law and Administration Course', the trainers can use a range of methods for taking the sessions like lecture, lecture followed by discussion, group discussion, role play, brainstorming, syndicate discussion, field visit, book review, simulation exercise etc. Use of different techniques during teaching sessions facilitate the trainees to acquire the knowledge and skill even better. Despite many option available as per course guidelines, the respondents argued that the most popular format during the sessions was traditional lecture method, i.e. $80 \%$ of the respondents agreed that the sessions were mostly based on lecture method (see table 03 ). 
Table 03. Methodology of teaching during the sessions

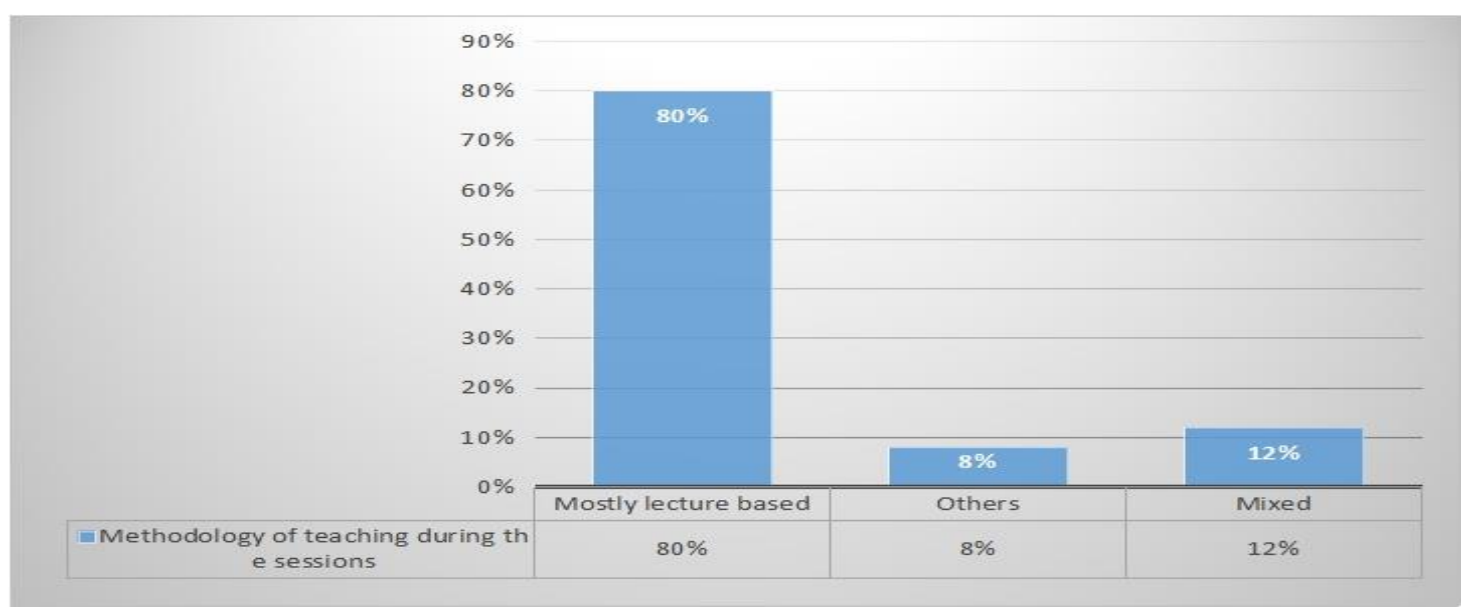

Another predominant factor which greatly influence the training outcomes are the use of ICT facilities. According to the annual report of BCSAA (2017-2018), classrooms are also provided with Wi-Fi connection. E-learning platform has been introduced in BCSAA in the recent past as a pilot project with the technical and financial assistance from Access to Information (a2i) program of Prime Minister's Office (PMO). These recent inclusions is reflected by the feedback received from the respondents where $84 \%$ respondents agreed to the fact that ICT tools effectively used during the training sessions (See figure 10).

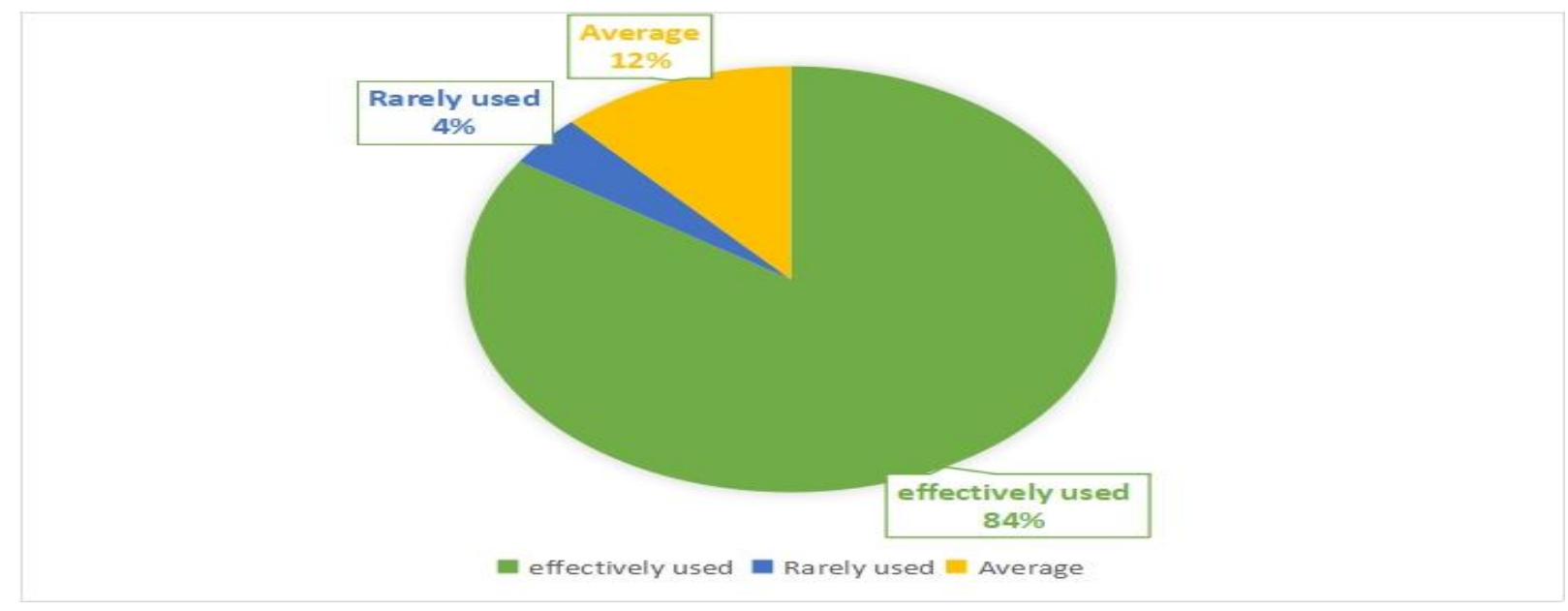

Figure 10: Use of ICT tools during training sessions

However, the overall perception among the respondents was quite diversifying regarding the ICT facilities for both trainers and trainees. Around 39\% of the total respondents expressed their satisfaction about the existing ICT facilities, while 27\% felt that it was average and 34\% respondents expressed their dissatisfaction regarding these provisions (See table 04). 


\section{Macrothink}

Table 04. Level of satisfaction regarding ICT facilities for both trainers and trainees

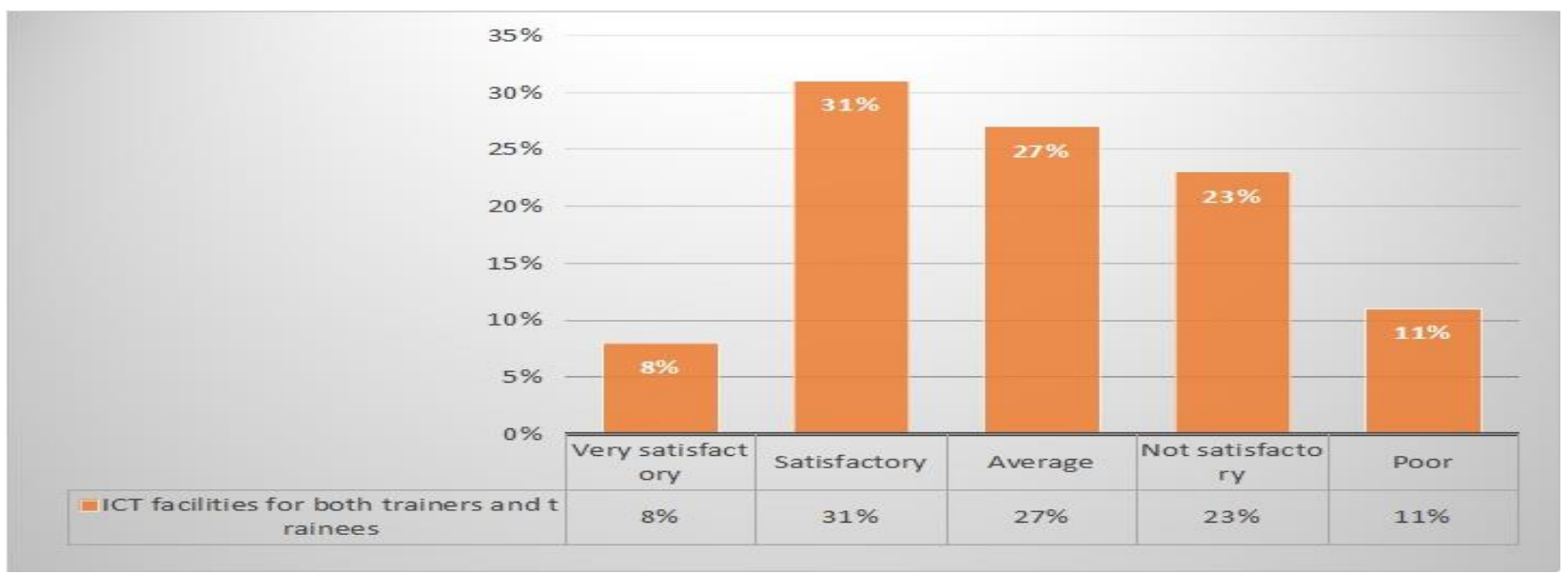

Quality of sessions improve if there are provisions for trainees to actively participate in discussion which leads to a two way interactive learning process. Almost half of the participants $(46 \%)$ felt that the sessions of Law and Administration course was both participative and lively. On the contrary, only $15 \%$ of the respondents found the sessions to be less participative and boring. Quite alarmingly, it was found that $39 \%$ of the respondents were unsure about the quality of the sessions, i.e. whether they were participative, lively or boring one (See figure 11).

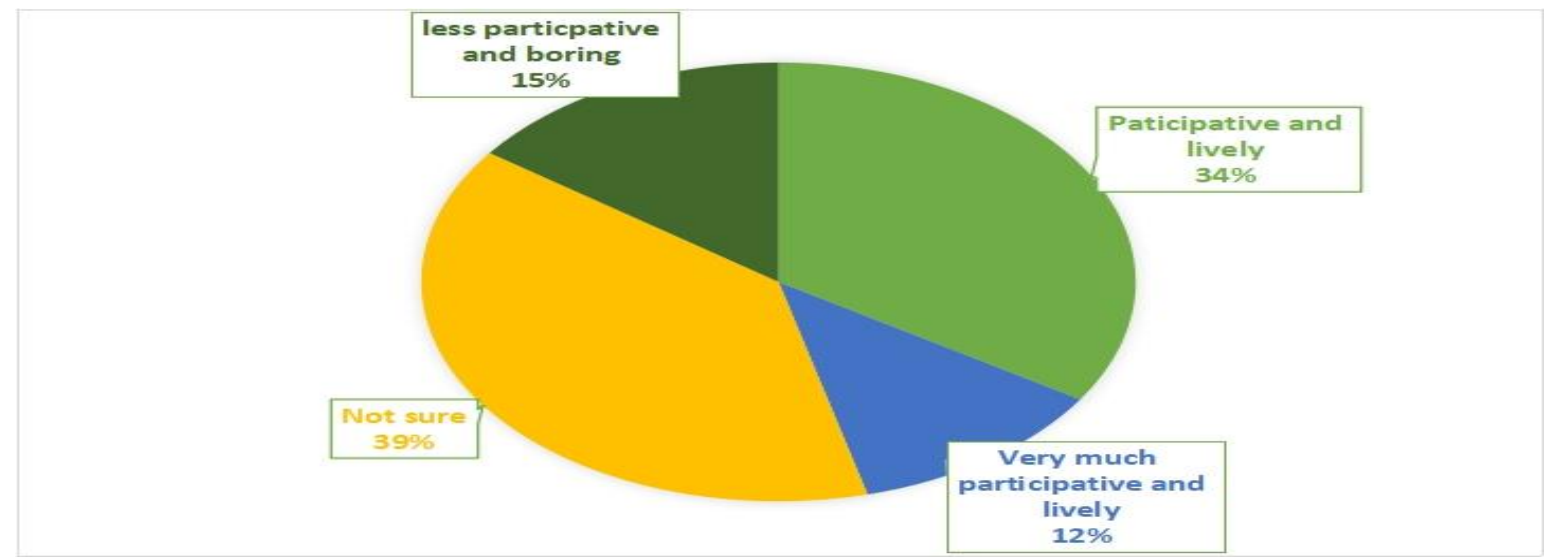

Figure 11. Quality of sessions

It is not only the course content, quality trainers, availability of the ICT facilities, teaching techniques but also the institutional facilities (which include dormitory, classroom, dining, library and medical) which determine the effectiveness of a training program. These institutional facilities become more pertinent where the nature of the training is a residential one like 'Law and Administration course'. When the respondents were asked about their level of satisfaction with the institutional facilities of BCSAA, $49 \%$ opined that they were satisfied with the provisions. However, more than one third of the respondents, i.e. $39 \%$ complained 


\section{Macrothink}

Journal of Public Administration and Governance

ISSN 2161-7104

2020, Vol. 10, No. 4

that they were dissatisfied with the existing various institutional provisions of the academy (see figure 12).

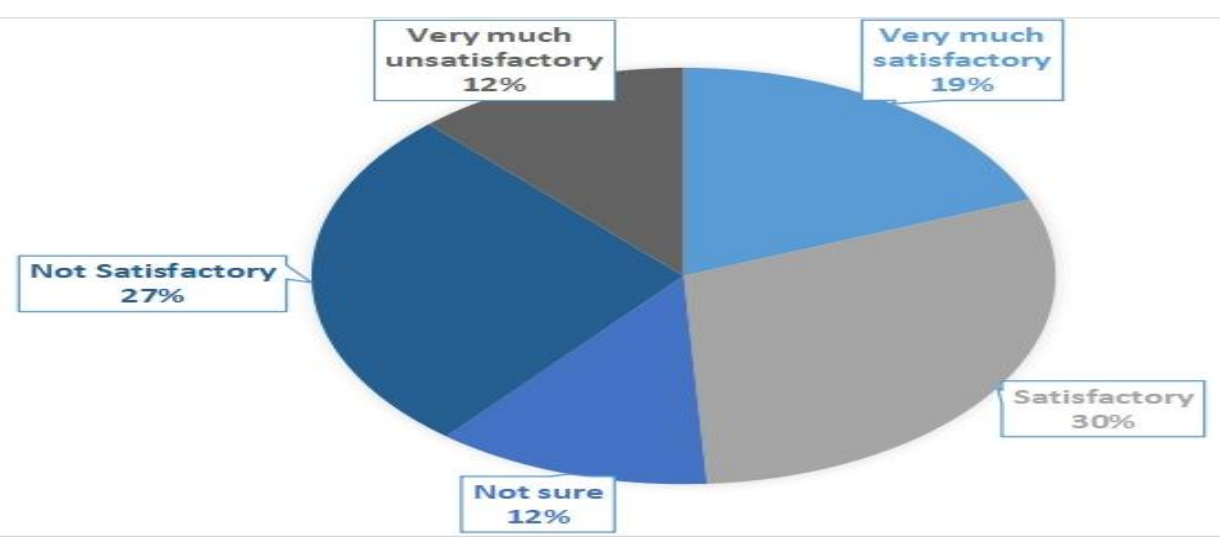

Figure 12. Institutional facilities (Classroom, dormitory, library, cafeteria and medical) of

\section{BCSAA}

Pre-test and post-test of the participants is very important for knowing what was the level of ASK of the participants before training and what changes have the training been able to successfully instil in them. More than two and a half portion of the total respondents $(84 \%)$ agreed to the fact that these tests were conducted objectively during the training program (see table 05).

Table 05. Pre-test and post-test of the participants

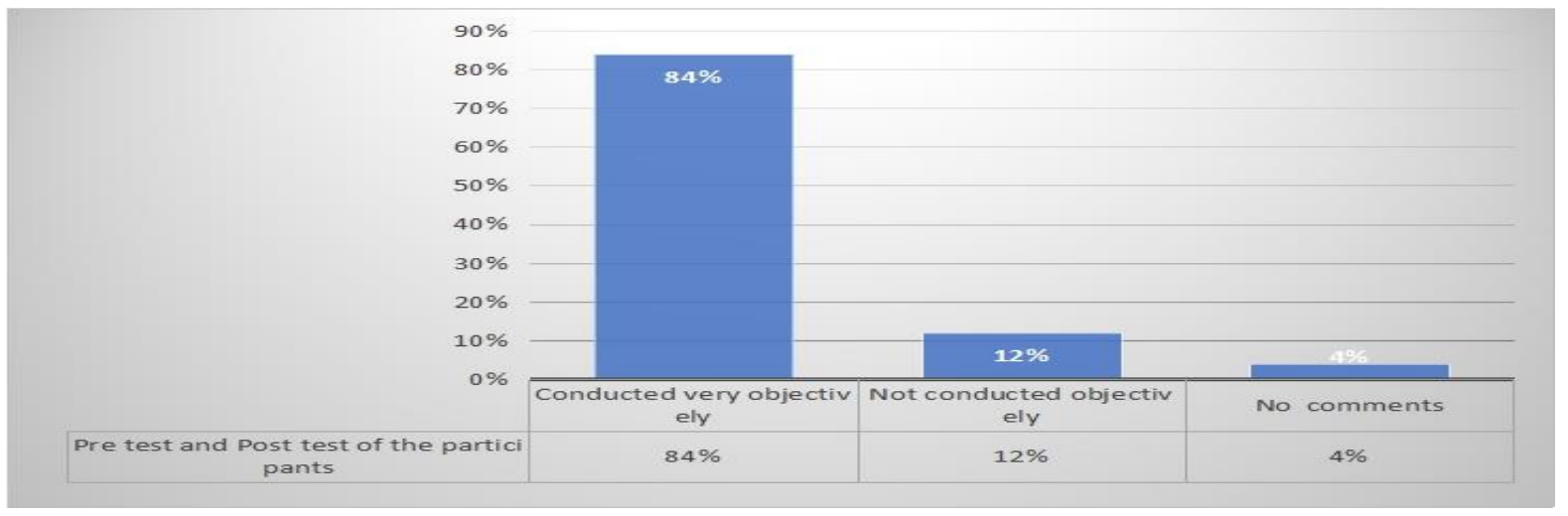

Trainers who train the participants aren't above appraisal rather their evaluation from time to time gives any institution whether to continue him/her as a facilitator of a course or not. Moreover, trainers also need to be trained with time. Hence, evaluation of the trainers can be very handy. According to the course guidelines of Law and Administration course, they have the provision to evaluate the trainers after each sessions using five criteria. More than two third of the total respondents, i.e. $72 \%$ noted that they conducted such evaluation of the trainers during their training (see figure 13). 


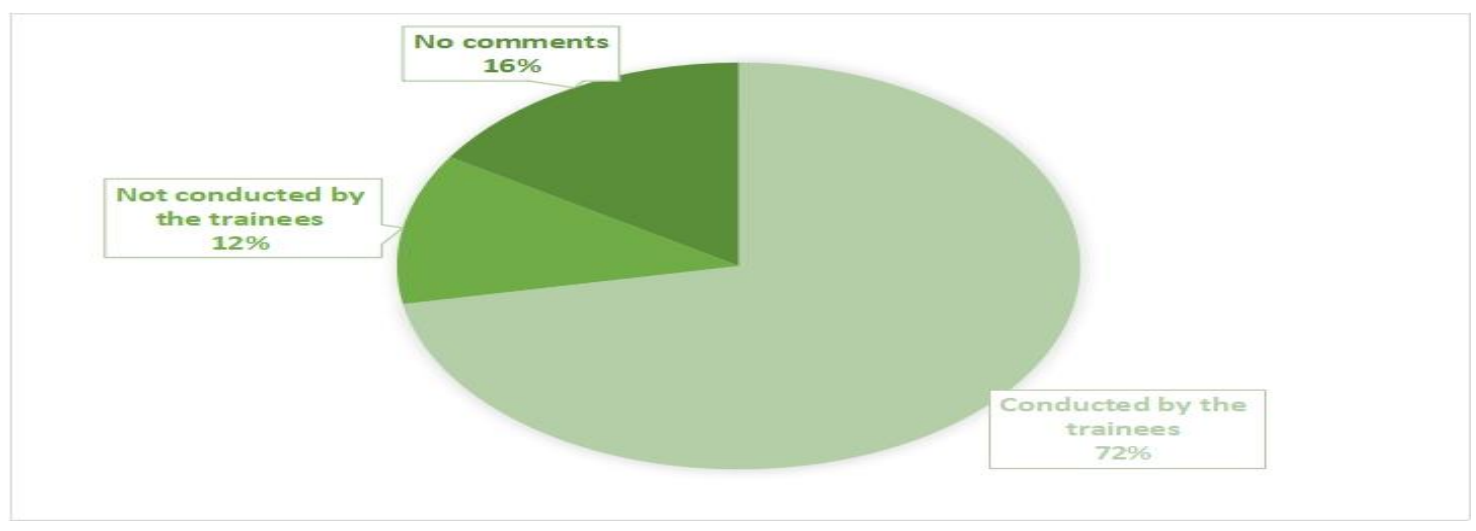

Figure 13. Evaluation of trainers

When the trainings are relatively long, residential and time consuming, it is commendable to add a refreshers training at the end of the course. These refreshers course have their potential benefits. The current course guidelines for law and Administration course does not have such provision. Nevertheless, for the further benefit of the participants, this can be incorporated in the future. Around $92 \%$ of the respondents acknowledged the advantages and value of such follow up trainings and recommended for such ones in the upcoming courses (See figure 14).
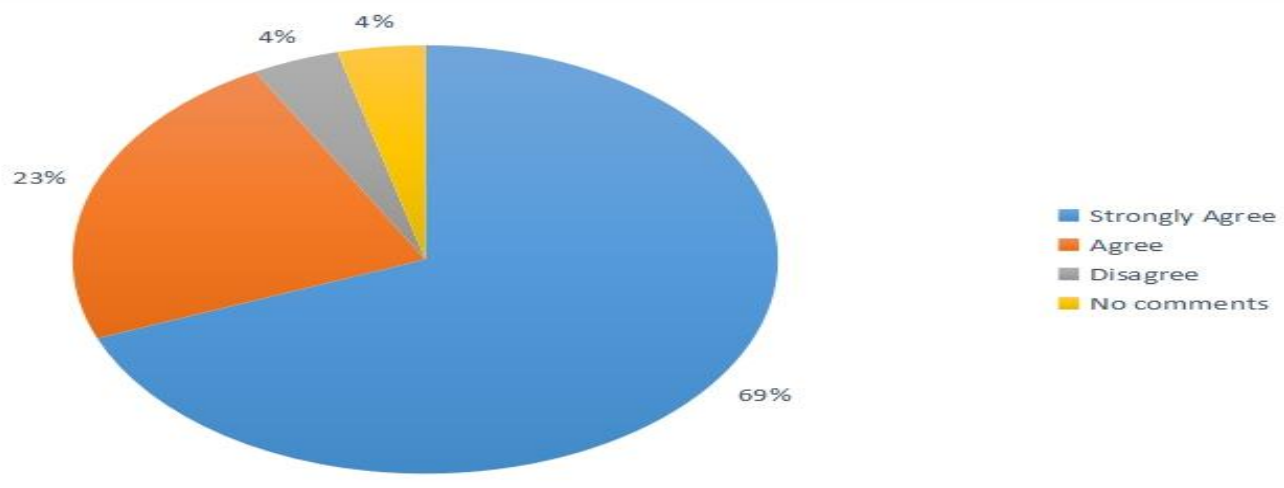

Figure 14. Need for a refreshers training

\subsection{Post Training Impact of the Law and Administration Course on the Trainees}

As mentioned earlier, LAC emphasizes on the criminal law, land law and its application that is clearly related to the job description of the administrative officers. Thus, about $70 \%$ of the total instructional sessions are devoted to the Criminal Procedure Code, The Penal Code, The Evidence Act, Land Law, The Civil Procedure Code, Constitutional Laws and Minor Acts. Most of the respondents agreed that this training has greatly helped them to perform their administrative, land related as well as judicial job with effectiveness and diligence. One of the respondent who is currently working as Assistant Commissioner (land) noted,

'This training has greatly benefited me. Had I not earned the knowledge from that training related to land management, things would have been really difficult for me.'

Again, most of the respondents have agreed that this training have greatly assisted them in 
providing the knowhow of mobile court conduction and magisterial duties. As this training puts upon too much stress on the various law, some of the respondents have shared their take away and potential benefits from acquiring knowledge regarding those laws. One of the participants noted,

"As a civil servant, we have to perform many duties. But as we are young and from diverse back grounds, it was difficult for me earlier in disposing my files efficiently. I lacked self-confidence owing to my limited knowledge related to various public laws. However, being trained from this particular course, now my confidence have increased. I can sense that I am being able to dispose more files now within short time adhering to the principles. Knowledge about various laws which I have learned from the training is helping me immensely'

Few respondents have stated that this training has enhanced their communication skills in English. One of the female respondents said,

'Previously my English communication skills was average. I realized that I needed to improve but due to work pressure, I could not do so. Nonetheless, I am extremely glad that things have gradually changed in a span of five months training in BCSAA for 'Law and Administration Course'. Medium of instruction for the entire course was English and so we all had to communicate with the fellow participants, faculty members in English. Moreover, we had to write several reports, assignments, do our presentation and all of these had to be done in English. Initially, it wasn't easy for me but I tried my best and it paid off. Now, I am much confident when it comes to present something or write a report in English'

Respondents also acknowledged about the fact that they have learnt few other useful things from the training like e-filing, e-mutation, Public Procurement Rules (PPR), process of making and use of ICT tools that is helping them in their respective workplaces.

\subsection{Issues and Challenges Related to Law and Administration Course Training}

It is true that this training has had positive effects on the trainees through improving their knowledge, skills, confidence, and attitude; there were certain issues which bothered some of the respondents. Firstly, for any training to be effective, need analysis is a must where the participants' knowledge gap is identified and accordingly he/she is recommended for a training. Few respondents noted that such mechanism rarely exists in most of the trainings in Bangladesh, including LAC. They argued that MOPA nominates the candidates without proper training need analysis. Albeit this training is a basic and mandatory one, mostly suitable at the nascent stage of the career, there are instances where a participant gets nominated at a later stage which results to demotivation for the participants.

Secondly, according to few respondents, the syllabus of this training course is humongous. Learning 21 modules within 5 months was a herculean task for them. One of the respondent opined, 'learning so many things in such a short time made us jack of all trades but master of none'. Few others have raised concerns about few contents on the training modules. They argued that there are certain common topics like Annual Performance Agreement (APA) which are already known to them. However, for discussion of those rather less important topics, few sessions are consumed, whereas certain topics of law which generally need more detailed discussion was found to have dearth of sessions. Again, few respondents also raised 
concerns about the evening sessions. They opined that in evening sessions, neither the trainers nor the trainees remain $100 \%$ and so recommended to decrease such ineffective sessions at that time through proper rationalization of session planning.

Thirdly, most of the respondents (around 62\%) felt that this training is too much dependent on guest speakers. Regarding the challenges of guest speakers, one of the participants said, 'There is no problem in hiring guest speakers for training because what they will share with us, we won't be getting that in books. Those are gold mines! However, problem arises when there is too much reliance on guest speakers. Each day, a guest speaker comes, delivers lecture and the next day, some one new comes and that was the common trend in most of the sessions in various modules. There was a lack of coherence among the sessions taken by the guest speakers which often made things complicated for us in comprehending'.

Fourthly, more than two third of the total respondents found that the delivery system in most of the sessions was lecture based (see the table 05) albeit the course guidelines provides a number of other options for using. One of the respondent stressing on the importance of more field visits and study tours noted that, "we really enjoyed our field attachments, study tour and group discussions as a part of our training. I still remember what I learnt practically through those visits by myself in contrast to what I have learned from so many lecture based sessions'.

Fifthly, few respondents raised their concerns about the institutional facilities of the BCSAA. They felt that ICT facilities of the academy was not up to expectation in this era of fourth industrial revolution. Moreover, they were dissatisfied with the absence of e-library facilities as the library of the academy remains closed during the weekends. A small number respondents also expressed their dissatisfaction with the staffs' behaviour. Meanwhile, a high percentage of respondents claimed that cutlery provisions in dining should have more variation because they had limited options to choose from.

Sixthly, few respondents expressed their dissatisfaction with the existing group assignment system. One of the respondents stated that, 'in group assignments, the groups exists only in paper. One or two group mates work with sincerity and the others remain dormant. However, all the members are rated equally which is unfair'. They suggested that individual assignment could be more effective means for evaluation in this regard.

Lastly, few respondents opined that application of the acquired skills and knowledge is not uniform for all the trainees. One of the respondents who had such perception stated,

'Undoubtedly I have learnt a lot of things from 'Law and Administration' course related to mobile court conduction, land management and I am very much confident that I can make the best use of my knowledge to serve my nation. Unfortunately, I am not being able to do so in my current workplace. What my other fellow colleagues can apply as an Assistant commissioner (Land), I will not be able to do so unless I get a similar placement.'

\section{Analyzing the Effectiveness of Training Approach of BCSAA}

Kirkpatrick (1976) noted that the trainings which are effective, the reaction phase reflects 


\section{Macrothink}

positive reaction of the participants. That is, they provide a positive feedback about the course content, training methodology, trainers, training sessions, institutional facilities and other aspects of training. The available data collected from the respondents reveal that their reaction was positive and satisfactory for certain factors. While there were also certain issues which did bother the trainees and hence resulted to a negative reaction towards the training. The table 06 illustrate these facts more explicitly.

Table 06. Reaction of the trainees about various aspects of training in BCSAA

\begin{tabular}{|c|c|}
\hline Positive Reaction & Negative Reaction \\
\hline $\begin{array}{l}\text { - Objectives of the training being } \\
\text { well defined } \\
\text { Presentation of the sessions } \\
\text { being well organized } \\
\text { - Discussion about training } \\
\text { objectives prior to training } \\
\text { - Content of the training being } \\
\text { relevant to the professional } \\
\text { needs } \\
\text { - Duration of sessions adequate } \\
\text { for effective delivery of content } \\
\text { - Availability and use of ICT tools } \\
\text { during sessions } \\
\text { - Tea with Rector and the faculty } \\
\text { members } \\
\text { - Study tour, field attachments, } \\
\text { public speaking, debate } \\
\text { - Availability of recreational } \\
\text { facilities } \\
\text { - Availability of library facilities } \\
\text { - Well-equipped } \\
\text { facilities dormitory } \\
\text { Provision for evaluating the } \\
\text { trainers }\end{array}$ & $\begin{array}{l}\text { - No provision for training needs } \\
\text { assessment } \\
\text { Too much reliance on guest } \\
\text { speakers } \\
\text { - More usage of lecture methods } \\
\text { despite other available } \\
\text { alternatives } \\
\text { - Huge course content compared } \\
\text { to course duration } \\
\text { - Absence of e-library } \\
\text { - Demerits associated with group } \\
\text { assignment } \\
\text { - English not always used as a } \\
\text { medium of instruction despite } \\
\text { the written guidelines } \\
\text { - Behavior of staff } \\
\text { - No diversity in cutlery } \\
\text { - No provision of refreshers } \\
\text { training }\end{array}$ \\
\hline
\end{tabular}

The analysis of the reactions show that trainees had mixed opinion (both positive and negative reactions) about various factors of the training. And so, it cannot be said that the training approach of BCSAA is entirely effective basing only from analysis of 'reaction' determinant. 
Kirkpatrick (1976) further stated that the participants who tend to like a program, go on to achieve more learning than the participants who dislike a program. In the learning phase, in order to know the effectiveness of the training, several questions are asked like what difference have the training made to their ASK, what value has it added to their knowledge base and how are they applying their acquired knowledge from training at their previous/current work places. The available qualitative data collected from the respondents revealed that through the training, there have been significant improvements in the knowledge base and skills in these areas

- conduction of mobile courts

-laws related to land management

-presentation skills

- magisterial duties

-e-filing, e-mutation

-office management

-Public Procurement Rules and budget

Thus, it is seen that the training intervention has led to successful learning in many areas of the trainees. This has resulted to improved confidence level of the respondents which is aiding them to perform their administrative and managerial duties with more diligence, efficiency and effectiveness. Hence, the analysis of both 'reaction' and 'learning' phases signalize about the fact that despite the respondents weren't entirely happy with the overall aspects of training of BCSAA, the training has however facilitated them in enhancing their knowhow which has further increased their professional competence. Therefore, the inference that can be drawn from this is that

"The training approaches of BCSAA is effective although there are areas which need special attention for making it more effective".

\section{Concluding Remarks and Proposed Strategies}

Training in civil service aims at something beyond just effectiveness and efficiency of the administrative system. It is a set of purposeful efforts for transforming the civil servants into potential human resources, which is extremely crucial for a modern public administration (Rashid, 2008, p.134). Thus training, if properly crafted, not only provides trainees with right competencies for doing the job but also brings about positive and permanent change in their actions and behaviour. (Salas et al 2006, p. 473). The findings of this study suggest that the training approaches of BCSAA for LAC is effective to a certain extent, which has resulted in improved ASK of the respondents. Moreover, the training has also enhanced the confidence level of the respondents and aiding them to perform their administrative and managerial duties with more diligence, efficiency and effectiveness. Nonetheless, there are areas which need special attention for making it more effective which are as follows:

Training need assessment for any training is mandatory. MOPA should start doing this before nominating participants for training courses. 


\section{Mll Macrothink}

Journal of Public Administration and Governance

ISSN 2161-7104

2020, Vol. 10, No. 4

$\checkmark$ There is a need of revisiting the current modules and updating the contents. Few common contents like Annual Performance Agreement (APA) and can be replaced by more pertinent topics with detailed discussion relevant for this training like policy formulation and implementation, financial management, Public Procurement Act 2006, Public Procurement Regulations 2008 etc.

$\checkmark$ A total of $25-30 \%$ of the total sessions may be allocated to the relevant Guest Speakers.

$\checkmark$ Number of Resource Persons may be increased from the faculty members of BCSAA by providing them ToT. However, implementing such a recommendation with the present workload that BCSAA has, would be next to impossible. The academy usually runs 4-5 training courses at a time which often becomes quite challenging for them. This whole process involves the faculty members (19) of the academy which resulted the dependence on Guest Speakers in a training program. Hence, to decrease the dependence on guest speakers it is highly recommended to increase the number of post of the faculty members in the academy.

$\checkmark$ As specified in the training module, LAC should use a range of Teaching-Learning methods throughout the whole training program.

$\checkmark$ Number of field attachments may be increased for making the training more effective and providing more firsthand experience to the trainees

$\checkmark$ There is a need to revisit the total number of evening sessions which currently stands to a quarter of the total numbers of sessions, and rationalize them accordingly

$\checkmark$ There is a need of bringing improvement in the institutional facilities of the academy like introduction of e-library facilities, improving the existing ICT facilities, increasing diversification in cutlery options of dinning and allowing library to remain open in the weekends.

$\checkmark$ The existing group assignment system may be replaced by individual assignments if needed. However, through group work, few specific skills of the participants can be assessed like leadership, communication, presentation etc. which individual assignments might fail to gauge properly. Of course, it completely depends on the trainers' capabilities and efficiency how a trainer will involve all the participants to assess their different skills through group work. Therefore, in order to prepare a trainer for conducting effective group works' assignments, they should be trained during ToT.

$\checkmark$ This study strongly recommends for a refreshers training for the trainees after a certain time of each training program.

\section{Acknowledgements}

We wish to convey our sincere thanks to BCSAA for initiating and funding this study. We further acknowledge the efforts put by the respondents of $113^{\text {th }}, 114^{\text {th }}$ and $115^{\text {th }}$ Law and Administration Course (LAC) conducted by BCSAA, for spending their precious time in participating the questionnaire survey and phone in interview and providing their valuable insights that has helped to furnish this study. 


\section{References}

Abdullah, L., \& Yazam, M. S. (2009). Factors that affect training effectiveness at semiconductor wafer fabrication industry in Malaysia. Journal of US-China Public Administration, 6(4), 10- 22.

Ali, M. H., Islam, M. S., \& Quader, M. A. (1998). Effectiveness of Foundation Training Course. Dhaka: BPATC.

Ali, A. M. S. S. (2007). Civil Service Management in Bangladesh: An Agenda for Policy Reform Dhaka: UPL.

Aziz, S. F. A. (2013). Measuring training effectiveness: Evidence from Malaysia. Paper presented at International Conference on Economic, Finance and Management Outlooks, At Pearl International Hotel, Kuala Lumpur, Malaysia. Retrieved $22^{\text {nd }}$ October, from https://www.researchgate.net/publication/331464976_Measuring_training_effectiveness_Evi dence_from_Malaysia/citation/download

Baldwin, T. T., Magjuka, R. J., \& Loher, B. (1991). The perils of participation: Effects of the choice of training on trainee motivation and learning. Personnel Psychology, 44, 51-65. https://doi.org/10.1111/j.1744-6570.1991.tb00690.x

BCSAA (2019).'Bangladesh Civil Service Administration Academy, Retrieved $22^{\text {nd }}$ October, from www.bcsadminacademy.gov.bd

BCSAA (2018). Annual Report 2017-2018. Dhaka: BCS Administration Academy. Retrieved $22^{\text {nd }} \quad$ October, from http://bcsadminacademy.portal.gov.bd/sites/default/files/files/bcsadminacademy.portal.gov.bd /page/875491d9_5f73_4a2d_a129_c6cafc13ad96/2020-01-12-17-166f851303a01e35883d140 16fc45130ee.pdf

BCSAA (2016). Annual Report 2015-2016. Dhaka: BCSAA. Retrieved $22^{\text {nd }}$ October, from http://bcsadminacademy.portal.gov.bd/sites/default/files/files/bcsadminacademy.portal.gov.bd /page/875491d9_5f73_4a2d_a129_c6cafc13ad96/Annual\%20Report\%20Final.pdf

Bersin, J. (2008). The training measurement book. San Francisco: Pfeiffer/John Wiley \& Sons.

Cervero, R. M. (1988). Effective continuing education for professionals. San Francisco, USA: Jossey Bass Publishers.

Cheng, E. W. L., \& Ho, D. C. K. (1998). The effects of some attitudinal and organizational factors on transfer outcomes. Journal of Managerial Psychology, 13(5/6), 309-317. https://doi.org/10.1108/02683949810219873

Chong, L.G. (2005). Evaluating training effectiveness: An integrated perspective in Malaysia. (Unpublished doctoral dissertation), University of South Australia, Australia.

Ehsan, M. (2014). Bangladesh Civil Service Academy, Retrieved $22^{\text {nd }}$ October, from http://en.banglapedia.org/index.php?title=Bangladesh_Civil_Service_Administration_Acade my 
Gagne, R. M., \& Medsker, K. L. (1996). The conditions of learning: Training applications. Belmont. CA: Wadsworth.

Gautam, V., \& Gautam, S. (2011). Training and Development- Towards an Integrated Approach. $\left(6^{\text {th }}\right.$ ed.). India: Indian Society for Training and Development.

Giangreco, A., Carugati, A., Denmark, A., \& Sebastiano, A. (2010). Are we doing the right thing? Food for thought on training evaluation and its context. Personnel Review, 39(2), 162-177. https://doi.org/10.1108/00483481011017390

Giangreco, A., Sebastiano, A., \& Peccei, R. (2009). Trainees' reactions to training: an analysis of the factors affecting overall satisfaction with training. The International Journal of Human Resources Management, 20(1), 96-111. https://doi.org/10.1080/09585190802528417

Goldstein, L. (1993). Training in organizations: Needs assessment, development and evaluation ( $2^{\text {nd }}$ ed.). Monterey, CA: Brooks/Cole.

Goldstein, I. L., \& Ford, J. K. (2002). Training in Organization: Needs Assessment, Development and Evaluation, CA: Wadsworth

Ghosh, P., Joshi, J. P., Satyawadi, R., Mukherjee, U., \& Ranjan, R. (2011). Evaluating effectiveness of a training programme with trainee reaction. Industrial and Commercial Training, 43(4), 247- 255. https://doi.org/10.1108/00197851111137861

Griffin, R. P. (2010). Means and ends: Effective training evaluation. Industrial and Commercial Training, 42(4), 220-225. https://doi.org/10.1108/00197851011048582

Hand, H. H., Richards, M. D., \& Slocum-Jr., J. W. (2017). Organizational climate and the effectiveness of a human relations training program. Academy of Management Journal, 16(2). https://doi.org/10.2307/255321

Hasan, S. M. (2009). Post Training Utilization (PTU) of Foundation Training. Dhaka: BPATC.

Hayatullah, A. F. M. (2006). The Pursuit of Bangladesh Civil Service Administration Academy in Improving the Efficiency of the Officers of Bangladesh Administrative Service: A Critical Review. Dhaka.

Holton, E. F. (1996). The flawed four-level evaluation model. Human Resource Development Quarterly, 7(1), 5-21. https://doi.org/10.1002/hrdq.3920070103

Holton, E. F. (2005). Holton's Evaluation Model: New evidence and construct elaborations. Advances in Developing Human Resources, 7(37), 37-54. https://doi.org/10.1177/1523422304272080

Horgan, J., \& Muhlau, P. (2006). Human resource systems and employee performance in Ireland and the Netherlands: A test of the complementarity hypothesis. International Journal of Human Resource Management, 17(3), 414-439. https://doi.org/10.1080/09585190500521409

Huq, A. K. F., \& Safiullah, M. (1989). Assessment of Training Needs at Foundation Level. Dhaka: BPATC. 
Jahan, M., \& Monem, M. (2014). Human Resource Management in Bangladesh Civil Service. In Ahmed, N. (ed.). 40 Years of Public Administration and Governance in Bangladesh, 109-126. Dhaka: UPL.

Kabir, S. L., \& Baniamin, H. M. (2012). Civil service Training in Bangladesh: An Institutional Analysis of BPATC Role, Rhetoric and Reality. Dhaka: AH Development Publishing House:

Kirkpatrick, D. (1996). Evaluation in the ASTD Training and Development Handbook. (2 ${ }^{\text {nd }}$ ed.) in R.L. Craig (New York: McGraw -Hill, 1996), 294-312.

Kirkpatrick, D. (1959). Techniques for evaluating training programs. In Kirkpatrick, D. 1996. Great ideas revisited: Revisiting Kirkpatrick's four-level model. Training and Development, 50, 54- 57.

Kirkpatrick, D. L., \& Kirkpatrick, J. D. (2010). Evaluating training programs: The four levels ( $3^{\text {rd }}$ ed.). USA: Berrett-Koehler Publishers.

Leach, M., \& Liu, A. (2003). Investigating Interrelationships among Sales Training Evaluation Methods. Journal of Personal Selling \& Sales Management, 23(4), 327-339.

Lucidchart Content Team (n.d.). The Kirkpatrick Evaluation Model: How to Measure Training Effectiveness. $\quad$ Retrieved $22^{\text {nd }} \quad$ October, from https://www.lucidchart.com/blog/how-to-use-the-kirkpatrick-evaluation-model

McGuire, D., \& Jorgensen, K. M. (Ed.). (2011). Human Resource Development: Theory and Practice. London: Sage Publication.

MOPA (2018). Annual Report 2017-2018. Retrieved 22 $2^{\text {nd }}$ October, from http://old.mopa.gov.bd/uploads/2018/reports/Part-2.pdf

Noe, R. A. (1986) Trainees' Attributes and Attitudes: Neglected Influences on Training Effectiveness. Academy of management Review, 11, 736-749. https://doi.org/10.5465/amr.1986.4283922

Noe, R. A. (2010). Employee training and development (5 $5^{\text {th }}$ ed.). Boston: McGraw Hill.

Powell, J. L. (2009). Transfer initiation and maintenance of training: Employees'perception of the relative influences of transfer intentions, general self-efficacy (GSE) and supervisor support. (Unpublished doctoral dissertation), Chesterfield University, Falls Church, Virginia, USA.

Quinones, M. A. (1997). 'Contextual influences in training', in M. A. Quiñones and A. Ehrenstein (Eds.), Training for a Rapidly Changing Workforce (pp. 177-99). Washington, DC: American Psychological Association. https://doi.org/10.1037/10260-007

Rezvi, M. K. I. (2013). Effectiveness of the Pubic Administration Training: A Study on the Administrative Cadre Service in Bangladesh (Unpublished Thesis), KDI School of Public Policy and Management, Korea.

Roy, P. K. (2007). Follow up Study on Effectiveness of the Senior Staff Course, Dhaka: BPATC. 
Sapru, R. K. (1985). Civil Service Administration in India (New Delhi: Deep and Deep Publications)

Salas, E., Wilson, K. A., Priest, H. A., \& Gutherie, J. W. (2006), 'Design, Delivery and Evaluation of Training System', In Handbook of Human Factors and Ergonomics, ed. Gavriel Salvendy, Florida: John Wiley \& Sons. https://doi.org/10.1002/0470048204.ch18

Rashid, S. A. (2008). Civil Service at the Cross-road. Dhaka: Muktochinta Prokashona Pp-134.

Subhankar, D., Madhusmita, D., \& Manoranjan, M. P. (2019). 'A study on factors influencing training effectiveness'. Espacios, 40(7-15). Retrieved $22^{\text {nd }}$ October, from https://www.researchgate.net/publication/330533636_A_study_on_factors_influencing_traini ng_effectiveness

Tai, W. T. (2006). Effects of training framing, general self-efficacy and training motivation on trainees' training effectiveness. Personnel Review, 35(1), 51-65. https://doi.org/10.1108/00483480610636786

Towler, A., \& Dipboye, R. (2001) Effects on Expressiveness, Organizations, and Trainee goalorientations on training outcomes. Journal of Applied Psychology, 86, 664-673. https://doi.org/10.1037/0021-9010.86.4.664

Werner, J. M., \&DeSimone, R. L. (2012). Human Resource Development (6 ed.). USA: Thomson South-Western.

\section{Copyright Disclaimer}

Copyright for this article is retained by the author(s), with first publication rights granted to the journal.

This is an open-access article distributed under the terms and conditions of the Creative Commons Attribution license (http://creativecommons.org/licenses/by/4.0/). 